\title{
Penggunaan Model CIPP dalam Evaluasi Kurikulum Inti Pendidikan D-III Kebidanan
}

\author{
Lastri Mei Winarni, ${ }^{1}$ Tina Dewi Judistiani, ${ }^{2}$ Rovina Ruslami, ${ }^{3}$ Farid Husin, ${ }^{4}$ Endang Sutedja, ${ }^{5}$ Dewi M.D. Herawati, \\ Ponpon S. Idjradinata ${ }^{7}$ \\ ${ }^{1}$ Mahasiswa Program Studi Magister Kebidanan Fakultas Kedokteran Universitas Padjadjaran, \\ ${ }^{2,4}$ Departemen Obstetri dan Ginekologi Fakultas Kedokteran Universitas Padjadjaran, \\ ${ }^{3}$ Departemen Farmakologi Fakultas Kedokteran Universitas Padjadjaran, \\ ${ }^{5}$ Departemen Kulit dan Kelamin Fakultas Kedokteran Universitas Padjadjaran, \\ ${ }^{6}$ Departemen Ilmu Kesehatan Masyarakat Fakultas Kedokteran Universitas Padjadjaran, \\ ${ }^{7}$ Departemen Ilmu Kesehatan Anak Fakultas Kedokteran Universitas Padjadjaran
}

\begin{abstract}
Abstrak
Peningkatan kompetensi bidan menjadi isu penting dalam penilaian kualitas lulusan kebidanan. Badan Pengembangan dan Pemberdayaan Sumber Daya Manusia Kesehatan (BPPSDMK) mengeluarkan Kurikulum Inti 2011 untuk membantu dalam proses peningkatan pembelajaran pendidikan diploma kebidanan. Capaian pembelajaran mahasiswa kebidanan cenderung rendah dan tidak sesuai dengan harapan. Salah satu upaya untuk memperbaiki proses pembelajaran adalah melakukan evaluasi pelaksanaan kurikulum inti D-III kebidanan 2011 untuk mengetahui komponen kurikulum yang perlu diperbaiki. Tujuan penelitian ini mengevaluasi kurikulum inti pendidikan D-III kebidanan saat ini dengan model CIPP (Context, Input, Process, Product) dan menggali kurikulum yang dibutuhkan bagi pendidikan D-III Kebidanan agar lulusan bidan lebih profesional. Metode rancangan penelitian menggunakan pendekatan kualitatif dengan pendekatan fenomenologi dan paradigma konstruktivisme. Penelitian ini dilakukan pada institusi di 5 provinsi yaitu : DKI Jakarta, Banten, Jawa Barat, Jawa Tengah, dan Jawa Timur . Teknik pengumpulan data menggunakan wawancara mendalam terhadap 17 responden, yang terdiri dari pembantu direktur bagian akademik, dosen pelaksana kurikulum harian, kepala bidang administrasi akademik dan mahasiswa. Analisis data meliputi transkripsi wawancara mendalam, reduksi, melakukan koding, kategorisasi dan penentuan tema. Proses evaluasi menggunakan model CIPP (Context, Input, Process, Product). Hasil didapatkan bahwa komponen context yang terdiri dari SDM, peserta didik, manajemen, dukungan pemimpin, struktur kurikulum, standar kompetensi, beban belajar, isi kurikulum, dan dukungan pemerintah perlu diperbaiki. Komponen input yang terdiri dari target capaian pembelajaran, kemampuan dosen, sarana dan prasarana, kecukupan waktu pembelajaran, sumber informasi pengembangan kurikulum serta kualitas calon mahasiswa belum memadai. Komponen process yang terdiri dari koherensi pembelajaran, keterlaksanaan program, perumusan kurikulum, pemilihan strategi pembelajaran, pengorganisasian kurikulum, prosedur evaluasi, suasana akademik masih belum baik. Komponen product yang terdiri dari kualitas kemampuan mahasiswa, dampak perubahan kurikulum belum maksimal. Simpulan diperlukan perbaikan dalam komponen Context, Input, Process, dan Product serta proses penyusunan kurikulum inti, penguatan mata kuliah, dan penguatan soft skill untuk meningkatkan kualitas lulusan bidan.
\end{abstract}

Kata kunci : Implementasi kurikulum kebidanan, kurikulum, pengembangan kurikulum

Korespondensi : Jl. Prabu Siliwangi Pasar Kemis KM. 3 Tangerang Banten 15133, mobile 021-5921132/ HP 081283523051, e-mail yashamei2@gmail.com 


\title{
Using CIPP's Model to Evaluate D-III Midwifery's Core Curriculum
}

\begin{abstract}
Enhancement competence of midwives become an important issue in assessing the quality of midwifery graduates. Badan Pengembangan dan Pemberdayaan Sumber Daya Kesehatan Manusia Kesehatan (BPPSDMK) released a Core Curriculum 2011 to assist improvement in educational learning of midwifery diploma. Midwifery student learning gains tend to be low and not in line with expectations. One effort to improve the learning process is to evaluate the implementation of the core curriculum midwifery D-III in 2011 to determine the components of the curriculum that need to be repaired. To evaluate the core curriculum of the D-III midwifery education today with CIPP model (Context, Input, Process, Product) and explore the curriculum required for D-III school in order to graduate the professionals midwives. The study design used a qualitative approach with a phenomenological approach and constructivism. This research was conducted at the institution in 5 provinces namely: Jakarta, Banten, West Java, Central Java, and East Java. Data collection techniques using in-depth interviews of 17 respondents, consisting of auxiliary director of academic, lecturer implementing daily curriculum, head of academic administration and students. Data analysis includes in-depth interviews transcription, reduction, coding, categorization and Determination themes. The evaluation process uses a model CIPP (Context, Input, Process, Product). Results it was found that the component context consisting of HR, learners, management, support leaders, curriculum structure, competency standards, the burden of learning, curriculum content, and government support needs to be fixed. Component inputs consisting of the target learning outcomes, faculty capabilities, facilities and infrastructure, the adequacy of instructional time, curriculum development resources and the quality of students is not adequate. Component process consisting of instructional coherence, adherence to the program, the formulation of the curriculum, the selection of learning strategies, organizing curriculum, evaluation procedures, academic atmosphere is still not good. Component product consisting of a quality student ability, the impact of changes in the curriculum is not maximized. Conclusion needed improvements in the components of Context, Input, Process, and Product and process of preparing the core curriculum, strengthening courses, and strengthening soft skills to improve the quality of graduate midwives.
\end{abstract}

Key words : Curriculum, curriculum development, midwifery curriculum implementation 


\section{Pendahuluan}

Bidan merupakan tenaga kesehatan yang penting dalam membantu upaya percepatan penurunan AKI. Oleh karena itu pemerintah dan masyarakat membutuhkan tenaga bidan yang kompeten dan profesional untuk menjalankan program-program kesehatan, tetapi hal ini bertentangan dengan situasi saat ini tentag kualitas bidan. Menteri Kesehatan Ibu Nafsiah Mboi menyampaikan bahwa kualitas bidan mengalami penurunan, ${ }^{1}$ hal ini terkait dengan hasil uji kompetensi bidan pada tahun 2013. Peserta yang mengikuti ujian berjumlah 6.199 orang, jumlah peserta yang lulus uji kompetensi bidan 3.582 orang $(53,5 \%)$, dan yang belum lulus berjumlah 2.617 orang $(47,5 \%)$ dengan nilai rata-rata 41,08 dan nilai batas lulus 40,14. ${ }^{2}$ Di Indonesia terdapat 679 institusi D-III Kebidanan, dengan jumlah lulusan kurang lebih 30.000 lulusan setiap tahun. ${ }^{3}$ Kontribusi kelulusan uji kompetensi kebidanan di provinsi Jawa Barat sebesar 64,29\%, Jawa Tengah sebesar $70,73 \%$, DI Yogyakarta sebesar $87,32 \%$, dan Jawa Timur sebesar $66,54 \%$. $^{2}$

Fenomena tersebut memberikan gambaran bahwa kemampuan lulusan bidan saat ini belum sesuai harapan dan hal ini seharusnya tidak terjadi terkait dengan pentingnya peran bidan di masyarakat. Faktor yang mempengaruhi pencapaian kompetensi tersebut adalah proses pembelajaran yang dialami oleh mahasiswa kebidanan, kualitas pengalaman praktik mahasiswa, pelatihan kasus, serta kemampuan akademis mahasiswa. Penelitian pada tahun 2006 mengenai permasalahan yang dihadapi pendidikan bidan di Indonesia adalah terbatasnya pengalaman praktik (hands on) mahasiswa, terbatasnya partispasi dosen di lahan praktik, terbatasnya pemberian asuhan yang sesuai dengan standar praktik, serta ketidaksesuaian antara kebutuhan dan suplai lulusan dalam perencanaan kerja. ${ }^{4}$

Program pembelajaran serta pengalaman yang diperlukan oleh peserta didik perlu direncanakan sejak awal dalam bentuk dokumen kurikulum. ${ }^{5}$ Jika pencapaian pembelajaran mahasiswa yang rendah maka perlu ada evaluasi terhadap kurikulum baik dari segi dokumentasi serta implementasinya. Evaluasi kurikulum merupakan kegiatan yang luas, kompleks dan terus menerus untuk mengetahui proses dan hasil pelaksanaan kurikulum. Proses evaluasi kurikulum sangat penting dilakukan dalam penentuan kebijaksanaan pendidikan. Hasil evaluasi kurikulum dapat digunakan oleh para pengelola institusi pendidikan untuk memahami perkembangan peserta didik, memilih bahan kajian, memilih metode dan alat bantu pengajaran, memilih cara penilaian dan fasilitas pembelajaran. ${ }^{6}$

Proses evaluasi kurikulum dapat dilakukan dengan model CIPP. Model CIPP dapat membantu institusi untuk memutuskan apakah institusi perlu melakukan inovasi atau tidak. Model ini terbentuk dari 4 jenis evaluasi, yaitu evaluasi context (konteks), input (masukan), process (proses), dan product (hasil). Keempat evaluasi ini merupakan suatu rangkaian keutuhan, tetapi seorang evaluator bisa saja melakukan salah satu jenis evaluasi atau kombinasi jenis evaluasi tersebut. ${ }^{7}$

Komponen konteks yang dievaluasi terdiri dari sumber daya manusia, peserta didik, manajemen, dan dukungan pimpinan institusi. ${ }^{7}$ Komponen masukan yang dievaluasi terdiri dari target capaian pembelajaran, kemampuan dosen, sarana dan prasarana, kecukupan waktu pembelajaran, sumber informasi pengembangan kurikulum. ${ }^{8}$ Komponen proses yang dievaluasi yaitu koherensi pembelajaran, keterlaksanaan program, perumusan kurikulum, pemilihan strategi belajar, pengorganisasian kurikulum, dan prosedur evaluasi. ${ }^{8}$ Komponen produk yang dievaluasi terdiri dari kuantitas dan kualitas kemampuan mahasiswa serta dampak perubahan kurikulum. ${ }^{8}$ Tujuan penelitian ini mengevaluasi kurikulum inti pendidikan D-III kebidanan saat ini dengan metode CIPP (Context, Input, Process, Product) dan menggali kurikulum yang dibutuhkan bagi pendidikan D-III Kebidanan agar lulusan bidan lebih profesional.

\section{Metode}

Rancangan penelitian ini kualitatif dengan pendekatan fenomenologi dan pendekatan paradigma konstruktivisme. Penelitian ini dilakukan pada institusi di 5 provinsi yaitu: DKI Jakarta, Banten, Jawa Barat, Jawa Tengah, dan Jawa Timur. Populasi penelitian yang dapat dijangkau dan dapat mewakili subyek penelitian adalah semua Kepala Program Studi/ Pembantu Direktur/ Pembantu Ketua/ Dosen yang tergabung sebagai tim pengembang kurikulum di Institusi D-III Kebidanan serta mahasiswa D-III kebidanan yang sudah melaksanakan proses 
pembelajaran kurikulum inti pendidikan D-III Kebidanan 2011 yang berada di Pulau Jawa.

Jumlah institusi yang berada di Pulau Jawa adalah 293 program studi D-III kebidanan, 43\% dari seluruh jumlah Institusi D-III Kebidanan di Indonesia. Pembagian area wilayah secara kluster menjadi 5 provinsi, yaitu DKI Jakarta, Banten, Jawa Barat, Jawa Tengah, dan Jawa Timur. Setiap kluster di 5 wilayah provinsi dipilih 1 institusi pendidikan D-III kebidanan secara acak.

Teknik pengumpulan data penelitian ini menggunakan wawancara mendalam terhadap 17 responden, yang terdiri dari pembantu direktur bagian akademik, dosen pelaksana kurikulum harian, kepala bidang administrasi akademik dan mahasiswa. Analisis data meliputi transkripsi wawancara mendalam, reduksi, melakukan koding, kategorisasi dan penentuan tema.

Menjaga keabsahan data dalam penelitian kualitaif maka peneliti menerapkan prinsip trustworthiness yang terdiri dari credibility, depenability, dan comfirmability. Peneliti menerapkan prinsip triangulasi dengan cara melakukan wawancara serta diskusi kelompok terfokus kepada mahasiswa, staf dosen serta bagian administrasi akademik

\section{Hasil}

Didapatkan bahwa komponen context yang terdiri dari SDM, peserta didik, manajemen, dukungan pemimpin, struktur kurikulum, standar kompetensi, beban belajar, isi kurikulum, dan dukungan pemerintah perlu diperbaiki.

\section{Sumber daya manusia}

Dalam pelaksanaan kurikulum memerlukan keterlibatan banyak pihak, yaitu kaprodi, dosen, tenaga kependidikan, pembimbing klinik. Ketua program studi merupakan pemain penting dalam pelaksanaan perubahan kurikulum di perguruan tinggi.

Berdasarkan hasil wawancara peneliti menemukan bahwa dalam pelaksanaan kurikulum 2011, semua responden dosen tidak mendapatkan kesempatan yang sama dalam mengikuti pelatihan, lokakarya, ataupun workshop tersebut. Hal ini terkait dengan jabatan struktural dan dukungan dana dari institusi. Seperti diungkap dalam kutipan di bawah ini:

“..Ya klo pelatihan gratis ok, tapi klo bayar nanti dulu, klo mau ya bayar sendiri....(RD1)"

\section{Peserta didik}

Berdasarkan wawancara adanya perubahan kurikulum memiliki efek secara langsung kepada mahasiswa melalui pembelajaran. Ada responden yang menyatakan bahwa pembelajaran teori yang berat di awal tahun menyebabkan mahasiswa belum matur dalam menerima pembelajaran tersebut. Efek kedua yang dirasakan mahasiswa adalah perasaan bingung ketika praktik di lahan, karena tidak semua institusi menerapkan kurikulum 2011.

\section{Manajemen}

Hasil penelitian menunjukkan bahwa sebagian besar institusi memiliki keterbatasan perencanaan dalam pelaksanaan kurikulum. Para pengembang kurikulum melaksanakan sama persis dengan kurikulum inti 2011 dan ditambahi mata kuliah muatan lokal, tanpa dilakukan kajian yang mendalam mengenai kebutuhan belajar dan kebutuhan masyarakat pengguna. Hal ini dipengaruhi oleh keterbatasan dukungan finansial dari institusi pendidikan. Hal ini dijelaskan seperti kutipan di bawah ini:

“....Nah dari pedomannya itu aja yang agak beda, disini kan masih ada sistem ...sebenernya apa yang dimaunya itu bagus, tapi pada praktik pelaksanaannya itu yang tidak terencana dengan baik. Misalnya kita sekarang nih mau merubah kurikulum, ya udah tinggal rubah aja, kadang-kadang kita nih merubahnya tidak disertai dengan yang serius, jadi jangan hanya berubah mata kuliahnya saja, atau pindah kemana, tapi isinya juga perlu berubah....(RU12)"

\section{Dukungan pemimpin}

Penemuan di lapangan peran pemimpin institusi sudah cukup baik dalam memberikan dukungan pada pelaksanaan kurikulum, sedangkan peran yayasan sangat bertentangan, dalam arti yayasan sangat mendukung proses pelaksanaan kurikulum inti 2011 tetapi kurang mendukung dari segi pendanaan maupun penambahan jumlah staf dosen. Hal ini dijelaskan dalam kutipan berikut:

\section{Struktur kurikulum}

Berdasarkan hasil wawancara menunjukkan bahwa sebagian besar responden melakukan penambahan bidang studi, pengembangan kurikulum, penambahan muatan lokal, 
perubahan distribusi mata kuliah, penambahan bahan kajian, pengurangan bahan kajian, serta merubah urutan pembelajaran. Hal tersebut tentunya merubah struktur kurikulum inti 2011. Tindakan-tindakan tersebut dilakukan atas dasar pertimbangan bahwa kurikulum inti memiliki topik pembelajaran yang kurang dalam bidang anatomi fisiologi, kemudian pada satu semester mempelajari bahan kajian yang terlalu banyak. Hal ini terjadi pada susunan mata kuliah di semester III, terjadi penumpukan mata kuliah asuhan kehamilan, persalinan, bayi baru lahir, masa nifas yang dipelajari secara bersamaan. Hal ini dijelaskan melalui kutipan sebagai berikut:

“...ini lho semester 3 asuhan kehamilan yang digabung dengan asuhan persalinan, itu klo dia jalan apa ga pusing anak-anak, orang jalan kehamilan sekaligus dikasih persalinan, klo kurikulum yang lama itu kan dia kehamilan dulu baru persalinan jadi orang itu tahu konsepsi dulu baru melahirkan, bukan melahirkan sama hamil jalan bareng...(RU6)"

\section{Standar kompetensi}

Berdasarkan hasil wawancara ditemukan pula bahwa kurikulum inti memiliki ketidaksesuaian dengan standar kompetensi. Oleh karena itu, beberapa institusi melakukan penambahan standar kompetensi sesuai dengan standar kompetensi yang diakui oleh profesi Ikatan Bidan Indonesia (IBI). Hal itu dijelaskan dalam kutipan berikut :

"....Harusnya di dalam standar kompetensinya, misalnya etikolegal disana bisa ditambahkan dengan pengembangan kepribadian jadi ada beberapa kali pertemuan, dan ada topiknya dikasih kurikulum inti, dikasih pokokpokoknya....(RD3)"

\section{Beban belajar}

Berdasarkan hasil wawancara diketahui bahwa pembagian SKS (Sistem Kredit Semester) perlu seimbang antara teori dan praktik. Menurut pengamatan peneliti, secara tertulis dan sesuai dengan prosedur, pendidikan kebidanan sebagai pendidikan vokasional telah membagi bahwa $60 \%$ pendidikan berisi praktikum. Hanya saja hal ini tidak tercermin dalam proses pelaksanaannya. Banyak SKS praktik yang tidak dilaksanakan oleh beberapa institusi. Berikut dijelaskan dalam kutipan di bawah ini:

“...sering sih bu, ada beberapa memang kita lihat di dalam silabus tertera (pembelajaran praktik), tapi mahasiswa belum mendapatkan....(RU14)"

\section{Isi kurikulum}

Berdasarkan wawancara diketahui bahwa responden memerlukan pengembangan bahan kajian dan merinci bahan kajian. Responden juga memaparkan bahwa mereka mengalami kesulitan dalam melakukan proses tersebut. Hal ini menyebabkan terbatasnya bahan ajar dalam melaksanakan proses pembelajaran di kelas, laboratorium, ataupun di lahan praktik.

\section{Dukungan pemerintah}

Berdasarkan hasil wawancara responden juga memaparkan bahwa mereka memerlukan dukungan pemerintah dalam kestabilan kebijakan serta perbaikan kurikulum inti yang sesuai dengan kebutuhan nasional. Berikut kutipan yang menjelaskan hal tersebut:

Komponen input yang terdiri dari target capaian pembelajaran, kemampuan dosen, sarana dan prasarana, kecukupan waktu pembelajaran, sumber informasi pengembangan kurikulum serta kualitas calon mahasiswa belum memadai.

\section{Target capaian pembelajaran}

Berdasarkan wawancara semua responden menyatakan bahwa pada proses pembelajaran dengan menggunakan kurikulum inti 2011 belum mencapai target capaian pembelajaran. Hal ini teridentifikasi dari belum terlaksana pembelajaran diarea kompetensi pengembangan diri dan profesionalisme serta manajemen kepemimpinan dan kewirausahaan pada beberapa institusi. Hal itu akibat tidak terteranya area kompetensi di dokumen kurikulum inti 2011.

"...tapi kalo dari segi fakta real yang ada secara umum beredar di masyarakat adalah anak-anak sekarang dari segi skill nya agak berkurang, ya mungkin ada berbagai factor disini sendiri juga capaian pembelajaran yang dilihat dari segi nilai yang dicapai.... jarang sekali yang dapet cum laude, intinya ya sekarang mereka masih paling 2,7. Bahkan kalo kebijakan yang lama itu 2,0 itu sudah lulus...(R12)” 


\section{Kemampuan dosen}

Semua responden memaparkan bahwa kemampuan dosen sangat penting dalam suatu proses pelaksanaan kurikulum khususnya pelaksanaan pembelajaran. Kemampuan dosen terdiri dari kompetensi dosen dan pengalaman dosen. Semua responden juga menyadari bahwa mereka perlu meningkatkan kualitas dosen institusi dengan mengadakan peningkatan pendidikan atau pengadaan pelatihan dan workshop. Berikut kutipan yang menjelaskan hal tersebut :

“...sebagai dosen ya memang harus seringsering melakukan bed side teaching sama mahasiswanya dan harus membedakan ini, supaya ada kekhasan tersendiri...(RU6)",

\section{Sarana dan prasarana}

Berdasarkan hasil wawancara sebagian besar responden mengemukakan bahwa sarana dan prasarana untuk melaksanakan pembelajaran di Institusi mereka sudah cukup lengkap, hanya saja rasio dengan jumlah mahasiswa masih terbatas. Hal ini menyebabkan pembelajaran praktik mahasiswa berjalan secara bertahap. Hal tersebut dikemukakan responden sebagai berikut:

“....Sejauh ini sih kita tidak sampai kekurangan alat ya bu, ga ada masalah....tetapi klo dirinci alat satu per satu dengan jumlah mahasiswa ya masih kurang, tapi kita akalin aja supaya jumlah alat cukup dengan adanya jumlah mahasiswa....(RU14)"

\section{Kecukupan waktu pembelajaran}

Permasalahan yang timbul adalah urutan pembelajaran yang tidak sesuai, karena dalam semester 3 bobot mata kuliah serta kompetensi yang perlu dicapai terlalu banyak. Hal ini membuat para pengembang kurikulum melakukan tindakan perubahan distribusi mata kuliah. Hal itu dikemukakan sebagai berikut :

“...untuk waktu ga masalah, tapi mungkin untuk penempatannya itu yang perlu dievaluasi, kan seharusnya klo dulu setelah askeb 1, baru askeb 2 baru PKK 1, kemudian KDPK dulu baru praktiknya. Saya rasa mungkin klo bisa kembali lagi seperti dulu... (RU10)"

\section{Sumber informasi dalam pengembangan kurikulum}

Berdasarkan hasil wawancara diketahui bahwa seluruh responden menyatakan bahwa sumber informasi pengembangan kurikulum hanya berasal dari workshop nasional dan workshop internal. Responden tidak mengundang ahli atau pakar kurikulum untuk membantu proses perencanaan atau penyusunan kurikulum yang sedang dilaksanakan saat ini. Berikut dijelaskan dalam kutipan di bawah ini :

"....Kami tidak ada khusus untuk mengundang pakar tetapi adalah kita ikut workshop-workshop pengembangan kurikulum...(RU15)"

\section{Kualitas calon mahasiswa}

Hal ini terkait dengan fakta di lapangan bahwa kualitas calon mahasiswa tidak diperhatikan oleh institusi. Sistem seleksi mahasiswa dilaksanakan lebih longgar untuk menarik banyak peminat, padahal seharusnya proses rekrutmen dan seleksi mahasiswa, terkait dengan kriteria yang dibutuhkan oleh bidan.

Komponen process terdiri dari koherensi pembelajaran, keterlaksanaan program, perumusan kurikulum, pemilihan strategi pembelajaran, pengorganisasian kurikulum, prosedur evaluasi, suasana akademik masih belum baik. Terdapat hambatan pada proses pembelajaran, implementasi yang akan berpengaruh pada usaha belajar mahasiswa.

\section{Koherensi pembelajaran}

Berdasarkan hasilawancara diketahui bahwa koherensi pembelajaran dalam pelaksanaan kurikulum inti 2011 masih belum optimal. Hal ini terlihat dari ketidaksesuaiannya sekuens pembelajaran. Kesesuaian kurikulum juga turut mempengaruhi pembentukan sekuens belajar. Hal ini dikemukakan oleh responden sebagai berikut :

“...kadang-kadang teorinya kan klo masih semester 2 masih awam mbak ya, jadi klo diberi materi yang berat jadi gimana, kaya mutu ....KB, kespro dan pelayanan $K B$, apalagi di anatomi fisiologi si mahasiswa itu nilainya jelek misalkan, jadi nanti klo masuk di KB kaya IUD misalkan kaya ga ngerti... (RD2)" 


\section{Keterlaksanaan program}

Keterlaksanaan program yang ditemukan dilapangan adalah keterbatasan upaya implementasi, keterbatasan upaya perubahan, dan ketuntasan belajar. Hal ini dijelaskan dalam kutipan di bawah ini :

"....kenyataannya di lapangan itu satu pasien bisa dipake 2 sampai 3 mahasiswa, klo kita tidak mengajarinya dari awal di pendidikan, nanti dia dapat apa, dan lo pun kita target ya, klo target yang di kurikulum baru kan diturunkan menjadi $50 \mathrm{ibu}$ hamil itu beda lho klo dibimbing dosennya sama dibimbing oleh orang lahan....(RU6)"

\section{Perumusan kurikulum}

Berdasarkan hasil wawancara sebagian responden menyampaikan bahwa perumusan kurikulum dipengaruhi oleh keterbatasan dokumen kurikulum inti, kemampuan serta pemahaman tim pengembang, dan dipengaruhi oleh kurikulum lama. Perumusan kurikulum yang baik akan mempermudah proses perencanaan dan penyusunan kurikulum. Jika perumusan kurikulum belum optimal, maka proses perencanaan dan penyusunan kurikulum pun tidak optimal, hal ini akan memengaruhi proses pelaksanaan kurikulum. Berikut penjelasan responden melalui kutipan di bawah ini :

\section{Pemilihan strategi pembelajaran}

Pemberian kasus dan pembelajaran kelompok merupakan cara belajar yang paling sering digunakan di institusi pendidikan kebidanan. Berikut penjelasan responden seperti kutipan di bawah ini:

“...Oh disini masih di kombine ya, tapi ya masih banyak teacher center sih mbak dari pada student center, karena disini masih sulit mbak...(RU15)"

\section{Pengorganisasian kurikulum}

Berdasarkan hasil wawancara dalam proses pelaksanaan kurikulum memerlukan pengorganisasian kurikulum. Aktivitas pengorganisasian kurikulum ini dilakukan responden dengan cara melakukan perubahan distribusi mata kuliah dan menyesuaikan antara pembelajaran teori dan praktik. Keterbatasannya dalam pengorganisasian kurikulum ini adalah tidak adanya pedoman petunjuk teknis yang digunakan sebagai acuan dalam pelaksanaan kurikulum.

\section{Prosedur evaluasi}

Berdasarkan hasil wawancara diketahui bahwa hampir semua responden menyatakan tidak pernah melakukan evaluasi dalam bentuk formatif. Evaluasi hanya dilakukan pada akhir pembelajaran semester yang melihat nilai ujian akhir semester untuk kategori pengetahuan dan nilai ujian praktik untuk kategori keterampilan.

\section{Suasana akademik}

Berdasarkan hasil wawancara diketahui bahwa masih terbatasnya pembentukan suasana akademik di institusi responden. Hal ini mungkin disebabkan oleh belum terbangunnya budaya akademis yang aktif dan dinamis. Berikut penjelasan responden seperti kutipan di bawah ini :

“....dari dosennya sendiri kemarin sudah disuruh untuk magang, untuk menambah pengalaman, tapi dari kampusnya sendiri belum diterjunkan langsung ke bidan. Kan itu nanti baru semester 5 nanti, atau semester 6. Jadi ya klo ada yang pengen aja, terus sudah ada kenalan bidan itu bisa magang....(RM11)”

\section{Hambatan pembelajaran}

Berdasarkan hasil wawancara, diketahui bahwa hambatan belajar yang dialami oleh mahasiswa adalah kesulitan belajar, kesenjangan antara dunia teori dan praktik, budaya lahan praktik serta kurangnya referensi yang dapat mereka akses dengan mudah.

\section{Hambatan implementasi}

Berdasarkan hasil wawancara diketahui bahwa hambatan implementasi kurikulum inti 2011 adalah terbatasnya penjabaran kompetensi, kesulitan pelaporan dan EPSBED.

\section{Usaha belajar mahasiswa}

Berdasarkan hasil wawancara diketahui bahwa usaha belajar mahasiswa dapat berupa keaktifan mahasiswa dalam pembelajaran, adaptasi mahasiswa, melaksanakan belajar kelompok, kemandirian siswa, mengatur waktu belajar dan aspek fisik mahasiswa. Komponen product yang terdiri dari kualitas kemampuan mahasiswa, dampak perubahan kurikulum belum maksimal. 


\section{Kemampuan mahasiswa}

Penelitian ini tidak meninjau sampai sejauh kualitas lulusan, tetapi hanya sampai pada kualitas kemampuan mahasiswa. Kemampuan mahasiswa yang ditemukan dalam penelitian adalah kemampuan bermasyarakat, pengembangan keterampilan klinis, terbatasnya kemampuan komunikasi, dan menurunnya etika. Berikut hasil kutipan wawancara dengan responden :

“...Bagiannya yang perlu diperkuat itu ya skillnya mbak, terutama skill intinya, askeb 1 sampai askeb 5 aja klo dia jadi bidan di wilayah, perkuat materinya disitu dan skillnya disitu, tapi ya ini kadang-kadang juga buat masukan juga untuk kita, ga hanya di kita juga sih, Cuma dari segi etika anak-anak ini agak kurang, di kita pun disini juga agak kita rasakan... dalam komunikasi, bagaimana berkomunikasi dengan dosen atau dengan temannya, via sms atau langsung, dan seterusnya, via telepon, dan lainnya, ada banyak keluhan dari lapangan, dosen luar atau dosen pembimbingnya ... kemudian disiplin. Itu yang agak susah, kemudian bagaimana dia beradaptasi dengan lingkungan itu yang masih berat... (RU12)".

\section{Dampak perubahan}

Dampak tersebut berupa perbedaan pemahaman staf, perubahan perilaku, bertambahnya beban kerja dosen, dan upaya peningkatan keterampilan.

\section{Penguatan mata kuliah}

Penguatan mata kuliah ini berupa praktik klinik dasar, kebidanan komunitas, dokumentasi kebidanan, kewirausahaan, kegawatdaruratan, kemampuan diagnosa, dan home care. Berikut kutipan wawancara dengan responden :

“....Keterampilan klinis, karena apa anda kuliah jadi bidan, tujuan anda untuk melayani masyarakat kan, berarti harus terampil klo ga terampil mana bisa, itu yang paling penting mbak, maka keterampilan diri baru setelah itu terpenuhi baru etika, setelah etika baru pengembangan diri, nah pengembangan diri ini luas, bisa kembali ke etikanya...(RD5)"

\section{Penguatan softskill}

Penguatan soft skill dapat diintegrasikan dalam kurikulum untuk dilaksanakan pada saat pembelajaran di kelas, laboratorium, dan di lahan klinik. Penguatan soft skill untuk mahasiswa kebidanan dapat berupa peningkatan komunikasi, team work, kepemimpinan, etika profesi, etika dan kepribadian.

\section{Simpulan}

Diperlukan perbaikan dalam komponen Context, Input, Process, dan Product serta proses penyusunan kurikulum inti, penguatan mata kuliah, dan penguatan soft skill untuk meningkatkan kualitas lulusan bidan.

\section{Daftar Pustaka}

1. IBI. Kualitas Bidan Menurun. Jawa Timur: Majalah Bidan; 2014.

2. Hariyati S. Uji Kompetensi bagi Mahasiswa Bidang Kesehatan (Pembelajaran 2013 dan Kesiapan 2014). In: BPPSDMK BSdSP, editor. Jakarta. 2014.

3. HPEQ, DIKTI HP. Data Akreditasi Program Studi Kebidanan Per Februari 2012. 201218 September 2013]: Available from:

4. Gaurenti L, Walia I, Yan J, Suchaxaya P. SouthEast Asia Nursing and Midwifery Educational Institutions Network. Report First Meeting 7-10 May 2006. 2006

5. Kern DE, Thomas PA, Howard DM, Bass EB. Curriculum Development For Medical Education: A Six-Step Approach. Baltimore and London: The Johns Hopkins University Press; 1998.

6. Sukmadinata NS. Pengembangan Kurikulum Teori dan Praktek. Bandung: PT Remaja Rosdakarya; 2012.

7. Hasan H. Evaluasi Kurikulum. Bandung: PT Remaja Rosdakarya dan Sekolah Pascasarjana Universitas Pendidikan Indonesia; 2008.

8. Hamalik O. Manajemen Pengembangan Kurikulum. Bandung: PT Rosda Karya; 2010. 